ROCZNIKI TEOLOGICZNE

Tom LXVI, zeszyt $6-2019$

DOI: http://dx.doi.org/10.18290/rt.2019.66.6-9

\title{
BARIERY W KOMUNIKACJI I POPRAWA JEJ SKUTECZNOŚCI WE WSPÓLNOCIE PARAFIALNEJ
}

\author{
BARRIERS IN COMMUNICATION AND THE IMPROVEMENT \\ OF THE EFFECTIVENESS OF COMMUNICATION \\ IN A PARISH COMMUNITY
}

\begin{abstract}
A b stract. The article is a dissertation on the subject of the barriers in communication in a parish community and on the ways of dealing with this problem. The first part is devoted to the communication barriers between the parson and his clergy co-workers. The next part of the article is devoted to the problems in the communication between the parson and the actively engaged lay co-workers. The final part concerns the communication barriers between the parson and the whole community of parishioners. In the communication process in the parish the parson plays the key role as its manager and the shepherd, therefore, the article is mainly devoted to the difficulties in the communication between him and his co-workers and other parishioners. The difficulties in communication between parishioners are not so meaningful in the everyday life and activity of the parish community.
\end{abstract}

Key words: parish; communication; communication barriers; effectiveness of communication; parson; parishioners.

W parafii - podobnie jak w innych organizacjach - komunikacja odgrywa ważną rolę. Jest ona szczególnie ważna w przypadku proboszczów, będących kierownikami zespołów duszpasterskich oraz pasterzami wspólnot wierzą-

Ks. dr hab. DARIUSz LIPIEC, prof. KUL - Instytut Teologii Pastoralnej i Katechetyki Katolickiego Uniwersytetu Lubelskiego Jana Pawła II; adres do korespondencji: Al. Racławickie 14, 20-950 Lublin; e-mail: lipiec@kul.pl; ORCID iD: https://orcid.org/0000-0002-8890-2062

Rev. Dr. Hab. DARIUSz LIPIEC, Prof. of KUL - Institute of the Pastoral Theology and Catechetics at the John Paul II Catholic University of Lublin; address for correspondence: Al. Racławickie 14, 20-950 Lublin; e-mail: lipiec@kul.pl; ORCID iD: https://orcid.org/00000002-8890-2062 
cych. Komunikacja jest przede wszystkim istotnym elementem procesów zarządzania parafią oraz planowania, organizowania, kierowania i kontroli duszpasterstwa na jej terenie. Kolejnym powodem, dla którego komunikacja odgrywa ważna rolę w działalności pastoralnej proboszcza, jest możliwość poznawania parafian, ich religijności oraz uwarunkowań egzystencjalnych ich życia, a także otoczenia parafii. Ponadto proboszcz wiele czasu spędza na komunikowaniu się ze współpracownikami i parafianami oraz osobami spoza parafii. Znaczna część działalności pastoralnej opiera się na nawiązywaniu i podtrzymywaniu relacji z wiernymi i innymi osobami ${ }^{1}$. Komunikowanie jest procesem złożonym i określa się je jako „proces przekazywania informacji od jednej osoby do drugiej" 2 .

Dla proboszczów sprawujących kierownicze role w powierzonych im wspólnotach parafialnych oraz dla duszpasterstwa parafialnego, za które są oni odpowiedzialni, szczególne znaczenie ma komunikacja między nimi a zespołami pastoralnymi, składającymi się z wikariuszy, kapelanów, prefektów i innych duchownych, będących najbliższymi współpracownikami proboszczów. Duże znaczenie ma również komunikowanie się proboszcza ze świeckimi aktywnie zaangażowanymi z duszpasterstwo i apostolstwo na terenie parafii, do których należą członkowie rad duszpasterskich i ekonomicznych, zespołów Caritas oraz etatowi pracownicy parafii. Istotną rolę pełni także komunikowanie się proboszcza w poszczególnymi parafianami. Oni są powierzeni pasterskiej trosce proboszczów i do nich skierowana jest pastoralna aktywność ich i ich współpracowników. We wszystkich tych dziedzinach komunikowania się proboszczów we wspólnocie parafialnej mogą występować bariery, zaś ich zadaniem jest troska o poprawę skuteczności komunikacji.

Bariery w komunikacji między proboszczem a współpracownikami i parafianami mogą wynikać $\mathrm{z}$ indywidualnych uwarunkowań interlokutorów oraz mogą być natury organizacyjnej. Poprawa skuteczności komunikacji jest związana z poprawą zarówno umiejętności indywidualnych osób komunikujących się, jak i umiejętności organizacyjnych proboszczów ${ }^{3}$.

\footnotetext{
${ }^{1}$ Por. J.A.F. Stoner, R.E. Freeman, D.R. Gilbert, Kierowanie, Warszawa: Polskie Wydawnictwo Ekonomiczne 2011, s. 507.

2 R.W. Griffin, Podstawy zarzadzania organizacjami, Warszawa: Wydawnictwo Naukowe PWN 2004, s. 592.

${ }^{3}$ Tamże, s. 609-613.
} 


\section{BARIERY I POPRAWA SKUTECZNOŚCI \\ W KOMUNIKACJI PROBOSZCZA Z ZESPOŁEM DUSZPASTERSKIM}

Prezbiterium parafialne jest wspólnotą duchownych, którą można określić jako wspólnota życia i posługi. W życiu kapłańskim nie można oderwać życia osobistego od realizacji powołania i posłannictwa. „U kapłana życie i pełnione funkcje nie są czymś odrębnym, ale tworzą całość" 4 . Jedność życia i posługi kapłańskiej wynika z charakteru sakramentu kapłaństwa, przenikającego całe życie prezbitera we wszystkich jego wymiarach i nadającego mu charakteru służebnego wobec tych, do których jest on posłany. Z tego powodu prezbiterium parafialne można określić mianem wspólnoty, będącej wspólnotą życia i duszpasterskiego posługiwania. Opiera się ona na nadprzyrodzonych więzach sakramentalnych, dzięki którym duchowni zostali włączeni w tajemnicę Chrystusa Dobrego Pasterza oraz we wspólnotę kapłańską, jaką jest prezbiterium. Dlatego ,żaden prezbiter nie może oddzielnie i jako jednostka wypełnić dostatecznie swojej misji, lecz tylko wspólnymi siłami z innymi prezbiterami pod przewodnictwem tych, którzy stoją na czele Kościoła” (DP 7). Skuteczna komunikacja między proboszczem a jego współpracownikami jest konieczna ze względu na „wspólne życie kapłanów, zwłaszcza związanych z tą samą parafią, które obok wzmożenia działalności apostolskiej, daje wiernym przykład miłości i jedności” (DB 30).

Barierę w komunikacji proboszcza ze współpracownikami duchownymi tworzą dawane przez niego niespójne lub sprzeczne sygnały. Mogą one wynikać z niezdecydowania lub braku konsekwencji przy podejmowaniu decyzji. Planowanie pracy duszpasterskiej wiąże się z przydzielaniem obowiązków i zadań poszczególnym duchownym, a także z przyjęciem określonych sposobów działania i procedur koniecznych do zrealizowania przyjętych celów i zadań. Sprzeczne sygnały są wysyłane wtedy, gdy proboszcz interweniuje w wykonywane czynności, gdy nie ma po temu racjonalnych powodów. Dzieje się tak, gdy proboszcz zmienia określony i przyjęty sposób przygotowania do sakramentów czy prowadzenia przez wikariusza grup pa-

${ }^{4}$ R. KAMIŃSKI, Parafia miejscem realizacji duszpasterstwa, w: Teologia pastoralna, red. R. Kamiński, t. II, Lublin: Atla 2 2002, s. 46. 
rafialnych. Zmiany dokonywane przez proboszcza przyjmują niekiedy charakter arbitralny, bez wyjaśnienia powodu zmiany i konsultowania się z wikariuszami. Zmiana procedur oznacza wysłanie przez proboszcza sprzecznego sygnału. Połączona $z$ bezwzględnym egzekwowaniem władzy proboszczowskiej, zmiana taka tworzy barierę między proboszczem a współpracownikami, która osłabia fundamenty współpracy w przyszłości.

Podobne skutki w osłabieniu komunikacji, a w rezultacie dla osłabienia działalności pastoralnej, ma brak konsekwencji w rozstrzyganiu spraw trudnych. Do takich spraw należą decyzje o dopuszczeniu lub niedopuszczeniu do Pierwszej Komunii Świętej lub bierzmowania, odmowa pogrzebu według rytuału katolickiego i im podobne. Ustalone zasady, nierzadko na szczeblu diecezjalnym, wiążą się z określonymi decyzjami, idącymi niepomyślnie dla niektórych parafian, podejmowanymi przez wikariuszy. Brak konsekwencji w postępowaniu proboszcza uchylającego decyzje współpracowników i podejmowanie decyzji sprzecznych z zaleceniami władzy diecezjalnej powoduje osłabienie komunikacji między nimi ${ }^{5}$.

Powstawaniu barier sprzyjają sprzeczne deklaracje proboszcza dotyczące współpracy z wikariuszami z jego późniejszą praktyką. Deklaracje takie, dawane współpracownikom w czasie ich przybycia do parafii albo wtedy, gdy zlecane są im do wykonania określone zadania, nie są następnie respektowane. Co więcej, zgłaszający się o pomoc wikariusze spotykają się nie tylko z odmową, ale wręcz z niechęcią.

Bariery w komunikacji mają źródło w braku wiarygodności - zarówno proboszcza, jak i jego współpracowników. Problemy z wiarygodnością wynikają zazwyczaj z uprzedzeń oraz opinii, jaką mają duchowni, zanim trafią do zespołu duszpasterskiego. Prezbiterium diecezjalne jest wspólnotą, w której zazwyczaj wszyscy nawzajem się znają i mają określone wyobrażenie o pozostałych. Źródłem wiedzy ogółu prezbiterium o poszczególnych jego członkach są najczęściej ich najbliżsi współpracownicy. Ich opinie mają jednak charakter subiektywny. Na charakter współpracy, a także na opinię o współpracownikach ma wpływ zarówno przebieg wspólnej działalności, jak i poziom satysfakcji z niej wynikający. Jednak przebieg współpracy i satysfakcja z niej płynąca zależne są od obu stron: od indywidualnych oczekiwań i subiektywnej jej oceny. Opinie o proboszczu i współpracownikach mogą więc być obarczone dużą dozą subiektywizmu, dlatego traktowane są z dość dużą ostrożnością. Rozpoczynający współpracę duchowni, w zależno-

\footnotetext{
${ }^{5}$ Por. A. Kaczor, Kancelaria parafialna, w: Teologia pastoralna, t. II, s. 86-92.
} 
ści od oceny wiarygodności będących w obiegu opinii, darzą się mniejszym lub większym zaufaniem. Ono z kolei sprawia, że proboszcz lub wikariusze postrzegani są jako mniej lub bardziej wiarygodni. Rzadko jednak ufa się całkowicie opiniom o poszczególnych osobach, dlatego wiarygodność współpracowników weryfikowana jest w czasie realnej działalności.

Wiarygodność współpracowników jest także zależna od treści komunikatów. Zatajanie informacji lub ich części albo ich zniekształcanie zmniejszają poziom wiarygodności zarówno proboszcza, jak i jego współpracowników. Ograniczanie przez proboszcza dostępu do wiedzy potrzebnej wikariuszom w poważny sposób może ograniczyć zaufanie do niego, ponieważ takie postępowanie jest postrzegane właśnie jako brak zaufania. Podobnie gdy wikariusze nie informują proboszcza o wszystkich sprawach, o których powinni poinformować, powodują u niego ograniczenie zaufania do nich i umniejszają swoją wiarygodność.

Problem zaufania dotyczy nie tylko interlokutorów, lecz także spraw, jakie podejmują. Proboszcz może nie mieć zaufania do celów i sposobów duszpasterzowania podejmowanych przez wikariuszy. Niechętnie zgadza się na ich inicjatywy lub nie udziela zgody na ich realizację. Brak umotywowania decyzji przez proboszcza lub udzielenie tylko powierzchownych wyjaśnień sprzyja powstawaniu barier w komunikacji między tymi osobami. Także zlecanie inicjatyw mało zasadnych jest postrzegane przez wikariuszy jako podejmowanie działań zastępczych i tworzy bariery komunikacyjne.

Drugą grupę barier między proboszczem a współpracownikami stanowią bariery organizacyjne. Pierwszą z nich jest różnica władzy i statusu interlokutorów. Pełna władza, jaką ma proboszcz w parafii, umożliwiająca mu podejmowanie w pełni samodzielnych decyzji, nawet wbrew wszystkim współpracownikom, sprzyja powstawaniu dystansu między nimi oraz wiążących się z tym barier w komunikowaniu. Zwłaszcza autorytarny sposób sprawowania władzy przez proboszcza ogranicza dialog, a w skrajnych przypadkach może go całkowicie wyeliminować.

Do barier organizacyjnych zalicza się także różnice w percepcji i ocenie zjawisk. Różnice te wynikają z odmiennego wieku, doświadczenia duszpasterskiego i innych przyczyn. Sposób postrzegania współczesnego świata, ludzi, Kościoła i zachodzących zjawisk może prowadzić do ograniczenia komunikacji między proboszczem a współpracownikami, a co za tym idzie, także wzajemnego zaufania i współpracy.

Bariery w komunikacji mogą powstawać wskutek szumów informacyjnych i przeciążenia informacjami. Wielość i różnorodność informacji, jaka 
dociera do proboszcza od parafian i otoczenia parafii, może zakłócić budowanie prawidłowego obrazu życia religijnego w parafii. Należy liczyć się także z tym, że wiele osób próbuje manipulować informacjami przekazywanymi proboszczowi, dostarczając mu informacji zniekształconych, niepełnych lub nawet nieprawdziwych. Podobnie dzieje się w przypadku jego współpracowników, którym podaje się „spreparowane” informacje, aby - dostarczone proboszczowi - wywołały jego określone decyzje lub postawy. Szum i przeciążenie informacjami stanowią poważne ograniczenie w prawidłowym komunikowaniu się proboszcza ze współpracownikami, chociaż często obie strony zakłócają komunikowanie się w sposób nieświadomy.

Poprawa skuteczności komunikowania w prezbiterium parafialnym wiąże się z poprawą umiejętności indywidualnych, jak i umiejętności organizacyjnych. Poprawa umiejętności indywidualnych dotyczy zarówno proboszczów, jak i jego współpracowników, chociaż ze względu na pozycję proboszcza na pierwszy plan wysuwa się poprawa jego umiejętności komunikacyjnych. Podstawową umiejętnością wydaje się wiarygodność, która warunkuje przyjmowanie postawy otwartości przez współpracowników. Wiarygodność wiąże się z kolei ze stabilnością sfery emocjonalnej i konsekwencją w realizacji podejmowanych decyzji, a także z otwartością proboszcza na inicjatywy wikariuszy oraz zachęcaniem ich przez przełożonego do komunikowania mu wszystkiego, co ich zdaniem jest potrzebne dla rozwoju wspólnoty kapłańskiej działalności pastoralnej.

Dla poprawy skuteczności komunikowania konieczna jest wrażliwość na punkt widzenia interlokutora. Dotyczy to obu podmiotów dialogu, zwłaszcza jednak proboszcza, mającego autorytet urzędowy i wynikającą z niego pozycję dominującą. Proboszcz, który wie wszystko lub wie wszystko lepiej, nie poprawi komunikacji $\mathrm{z}$ podwładnymi. $\mathrm{Z}$ tego powodu jako ważne należy uznać doskonalenie umiejętności uważnego słuchania przekazu wysyłanego przez współpracowników.

\section{BARIERY I POPRAWA SKUTECZNOŚCI W KOMUNIKACJI MIĘDZY PROBOSZCZEM A WSPÓŁPRACOWNIKAMI ŚWIECKIMI}

Do najbliższych świeckich współpracowników proboszcza w duszpasterstwie należą członkowie parafialnej rady duszpasterskiej, rady ekonomicznej, parafialnego zespołu Caritas oraz etatowi pracownicy parafii. Na kształt życia religijnego $\mathrm{w}$ parafii oraz duszpasterstwa parafialnego największy 
wpływ mają członkowie gremiów parafialnych, zwłaszcza parafialnej rady duszpasterskiej. Ich zadaniem jest wspieranie proboszcza w podejmowaniu decyzji dotyczących działalności pastoralnej oraz ich realizacji ${ }^{6}$. Realizacją działalności pastoralnej w dziedzinie charytatywnej zajmują się członkowie parafialnego zespołu Caritas. Zarówno w procesie podejmowania decyzji, jak i organizowania oraz realizowania pracy duszpasterskiej $w$ parafii konieczna jest dobra komunikacja między proboszczem a zaangażowanymi świeckimi ${ }^{7}$.

Barierą często występującą w komunikacji między proboszczem a świeckimi współpracownikami są różnice w postrzeganiu rzeczywistości parafial$n e{ }^{8}$. Pierwszą z nich jest różnica w postrzeganiu religijności parafian. Wynika ona $z$ odmienności perspektywy oglądu i oceny: proboszcz stara się postrzegać parafian bardziej całościowo i integralnie, i na tej podstawie dokonywać oceny religijności parafii jako całości. Także ocena religijności poszczególnych parafian dokonywana jest w sposób bardziej racjonalny. Współpracownicy świeccy, żyjący pośród innych parafian, nie zawsze są w stanie zdystansować się od osób i zjawisk i dokonać oceny obiektywnej. Mają oni również skłonności do dokładnego postrzegania jedynie pojedynczych zjawisk i na ich podstawie dokonywania uogólnień oraz odnoszenia ich do całej wspólnoty parafialnej. Ich obserwacje mają jednak przewagę nad oglądem proboszcza w aspekcie szczegółowości: żyjąc pośród innych, mają szczegółowy obraz osób i zjawisk. Takiego obrazu proboszczowie często nie mają, ponieważ wielu parafian stara się ukryć wiele faktów ze swego życia lub przedstawiać je w bardziej korzystnym dla siebie świetle.

Różnice w postrzeganiu religijności parafian znajdują odbicie w różnym określaniu potrzeb parafii. $Z$ tego powodu stosunkowo często dochodzi do konfliktu między gremiami parafialnymi a proboszczem, ponieważ rozbieżnie postrzegane potrzeby implikują stawianie odmiennych celów dla duszpasterstwa. Jeśli dotyczy to ważnych dziedzin życia parafialnego, to konflikty mogą przybierać głęboki charakter ${ }^{9}$.

Bariera w komunikacji między proboszczem a świeckimi współpracownikami może mieć źródło w używanym języku. Proboszczowie używają często

\footnotetext{
${ }^{6}$ Por. R. KAMIŃSKI, Działalność zbawcza Kościoła w teorii i praktyce pastoralnej, Lublin: Wydawnictwo KUL 2007, s. 201-203.

${ }^{7}$ Por. I. CIEŚLIK, Przezwyciężý́ kryzys parafii, w: Nowa ewangelizacja u progu Trzeciego Tysiaclecia. Program duszpasterski na rok 2000/2001, red. E. Szczotok, R. Kempny, A. Liskowacka, Katowice: Kuria Metropolitalna 2000, s. 159-167.

${ }^{8}$ Por. J.A.F. STONER, R.E. FreEMAN, D.R. GilberT, Kierowanie, s. 512-513.

${ }^{9}$ R. KAMIŃSKI, Działalność zbawcza Kościoła w teorii i praktyce pastoralnej, s. 202-203.
} 
języka teologicznego oraz związanych z nim skrótów myślowych, nie zawsze zrozumiałych dla osób niemających wykształcenia teologicznego. Ponadto istnieją wyrażenia stosowane $\mathrm{w}$ środowisku duchownych, które mogą mieć inne znaczenie w środowisku laikatu, co prowadzi do nieporozumień.

Podobnie jak w komunikowaniu się między duchownymi, tak również w komunikacji między proboszczem a świeckimi barierę mogą stanowić uprzedzenia. Winy za nie może nie ponosić żadna ze stron. Dzieje się tak, gdy po sytuacji kryzysowej do parafii przychodzi nowy proboszcz. Uprzedzenia są wówczas udziałem zarówno parafian, którzy z nieufnością zwracają się do nowo przybyłego, jak i proboszcza, podejrzliwie przyglądającego się parafianom skonfliktowanym z poprzednikiem. Uprzedzenia mogą wynikać także ze złych doświadczeń we współpracy. Uprzedzić może się zarówno proboszcz, jak i świeccy, gdy któraś ze stron, w opinii interlokutorów, nie spełnia jej oczekiwań. Obstawanie przy własnym zdaniu powoduje w takim przypadku dalsze pogłębianie uprzedzeń.

Barierą jest też niechęć do komunikowania się. Niechęć ta może być udziałem zarówno proboszcza, jak i świeckich. Proboszcz może mieć przekonanie, że sam podejmuje lepsze i szybsze decyzje, a także że bez wsparcia gremiów parafialnych lepiej zrealizuje plany duszpasterskie. Nie wykazuje więc chęci do komunikowania się i kontakty ze świeckimi ogranicza do niezbędnego minimum. Niechęć do komunikowania się mogą wyrażać także świeccy, gdy uważają, że sprawy duszpasterskie są wyłącznie domeną duchownych i im oddają wszelką inicjatywę. Niechęć do komunikowania się świeccy w Polsce wyrażają w coraz większym zakresie. Mają oni ku temu wielorakie motywy, wśród których można wymienić ograniczanie przez proboszcza ich wpływu na życie parafii czy brak sympatii do jego osoby.

Przełamywanie barier i poprawa skuteczności w komunikowaniu w znacznym stopniu zależne są od empatii. Dotyczy ona w pierwszym rzędzie proboszcza, lecz jest niezbędna także w odniesieniu do świeckich. Sprzyja ona wyrabianiu umiejętności spojrzenia na rzeczywistość z punktu widzenia drugiej strony - słuchania, uczenia się i zdobywania nowych doświadczeń ${ }^{10}$.

Poprawa rozumienia treści komunikatu zależna jest od wzajemnego zrozumienia, co wiąże się ze zmianą języka i uczeniem się nowych pojęć. $Z$ tego powodu konieczna jest formacja intelektualna świeckich członków gre-

\footnotetext{
${ }^{10}$ Por. A. Petrowa-WASilewicz, Parafia przyszłości - dom otwartych drzwi, w: Nowa ewangelizacja u progu Trzeciego Tysiaclecia. Program duszpasterski na rok 2000/2001, red. E. Szczotok, R. Kempmy, A. Liskowacka, Katowice: Kuria Metropolitalna 2000, s. 172-174.
} 
miów parafialnych, zwłaszcza w zakresie teologii. Formacja taka jest także pomocna do lepszego rozumienia, czym jest Kościól, parafia oraz na czym polega powołanie i posłannictwo ludzi świeckich.

Przełamywaniu uprzedzeń, mających głównie podłoże emocjonalne, służy postawa otwartości proboszcza w stosunku do parafian. Im częstsze i dłuższe są ich kontakty, tym bardziej obie strony mogą się lepiej poznać i przekraczać istniejące uprzedzenia. Umacnianiu relacji służy natomiast stopniowe powierzanie coraz większej ilości zadań do wykonania i coraz większej samodzielności w ich realizacji. Sprzyja to wypracowywaniu odpowiedzialności świeckich za swoją parafię, a jednocześnie poprawia komunikację proboszcza z członkami gremiów parafialnych ${ }^{11}$.

\section{BARIERY I POPRAWA SKUTECZNOŚCI KOMUNIKACJI MIĘDZY PROBOSZCZEM A OGÓŁEM PARAFIAN}

Hierarchiczna struktura Kościoła sprawia, że komunikacja między proboszczem a parafianami przybiera charakter komunikacji pionowej. Poza osobami zaangażowanymi $\mathrm{w}$ działalność duszpasterską i apostolską parafii, ogół wierzących osobiście spotyka się z duszpasterzami średnio kilka razy w roku, zaś komunikacja między nimi nie ma charakteru interaktywnego. Przepowiadanie parafialne, działalność liturgiczna przebiegają według ściśle określonego porządku i nie wymagają znaczącej kreatywności od parafian. Komunikacja między proboszczem a wiernymi ma w dużym stopniu charakter formalny.

Informacje przekazywane przez duszpasterzy są przyjmowane na podstawie ich autorytetu religijnego i powinny być akceptowane z wiarą. Obejmuje to informacje dotyczące prawd wiary i moralności chrześcijańskiej. W podobny sposób przekazywane są informacje odnoszące się do życia parafialnego. Te jednak nie mają autorytetu wiary i nie są przez wiernych przyjmowane z uległością. Komunikacja odnosząca się do obu tych dziedzin wymaga interakcji ze strony parafian. Potrzebują oni wyjaśnienia i przybliżenia prawd objawionych, co może ułatwić stawianie przez nich pytań. Życie para-

\footnotetext{
${ }^{11}$ Por. D. LiPIEC, Problemy we wspótpracy duchowieństwa i laikatu, „Roczniki Teologiczne” 50(2003), z. 6, s. 231-246.
} 
fialne z kolei wymaga, aby mogli oni wyrazić swoje opinie i potrzeby oraz znaleźć odpowiednie sposoby zaangażowania w nie ${ }^{12}$.

Problemy w komunikacji między proboszczem a parafianami wynikają z braku dialogu lub jego ograniczenia do spraw wiary i moralności chrześcijańskiej. Przepowiadanie parafialne nie odpowiada w sposób wystarczający na pytania religijne i egzystencjalne współczesnych wierzących. Stanowi to barierę $\mathrm{w}$ pogłębianiu więzi $\mathrm{z}$ Bogiem $\mathrm{i}$ w rozwoju życia duchowego parafian.

Barierą w komunikacji jest również ograniczanie informacji dotyczących działalności parafii. Ogłoszenia i gazetki parafialne oraz informacje podawane na parafialnych stronach internetowych są zazwyczaj krótkie i zwię$z^{13}{ }^{13}$. Dla wielu parafian, zwłaszcza interesujących się życiem parafialnym w ponadprzeciętnym stopniu oraz pragnących bardziej w nie się włączać, informacje te są niewystarczające. Także brak możliwości szerszej interakcji z duszpasterzami nie sprzyja rozwojowi komunikacji parafialnej i ich zaangażowania w życie lokalnej wspólnoty. Taki model ograniczonej komunikacji wynika z klerykalnego sposobu pojmowania Kościoła i parafii oraz odpowiada wizji parafian, postrzeganych głównie jako adresatów działalności duchowieństwa ${ }^{14}$.

Poprawa skuteczności komunikacji między proboszczem a parafianami wymaga przede wszystkim przełamywania ograniczeń wynikających z charakteru komunikacji pionowej. Proboszcz może to zrobić, przyjmując postawę „wyjścia” do parafian i nawiązywania z nimi kontaktów pozaoficjalnych. Bezpośrednie spotkania z proboszczem sprzyjają wzajemnemu otwarciu się i poszerzają kanał informacyjny między nimi. To otwarcie może przyjmować charakter mniej lub bardziej spontaniczny. Do mniej spontanicznych spotkań dochodzi $\mathrm{w}$ czasie pracy $\mathrm{z}$ grupami religijnymi w parafii, takimi jak: koła różańcowe, chóry, schole, ministranci i inne grupy o charakterze formacyjnym. Bardziej spontaniczne spotkania mają miejsce wtedy, gdy proboszcz prowadzi politykę „otwartych drzwi” plebanii. Wówczas parafianie mogą przychodzić i komunikować się z nim w różnorakich sprawach religijnych i egzystencjalnych. Takie podejście sprzyja spotkaniom proboszcza z para-

12 Por. R. Kempny, Jaka parafia u progu Trzeciego Tysiaclecia?, w: Nowa ewangelizacja u progu Trzeciego Tysiaclecia. Program duszpasterski na rok 2000/2001, s. 166-167.

13 Por. J.P. Woźniak, Rozwój mediów w przekazie wiary $w$ archidiecezji lubelskiej po roku 1989, Lublin: Gaudium 2015, s. 85-96.

${ }^{14}$ Por. A. ŻĄDŁO, Modele organizacji duszpasterstwa parafialnego, w: Nowa ewangelizacja u progu Trzeciego Tysiaclecia. Program duszpasterski na rok 2000/2001, s. 178-179. 
fianami poza plebanią, w różnych miejscach i okolicznościach. Spotkania te umożliwiają rozwój komunikacji między tymi osobami i wspomagają budowanie wspólnotowości parafii.

W parafii istnieje również komunikacja pozioma - między poszczególnymi wierzącymi i ich grupami. Służy ona przede wszystkim budowaniu wspólnotowości parafialnej. Wymiana informacji między różnymi podmiotami powoduje, że parafia staje się wspólnotą ,poinformowaną”, a jej członkowie są bardziej świadomi tego, co się w niej dzieje. Powiększanie tej wiedzy ma na celu coraz szersze włączanie parafian w życie parafii. Chodzi o włączanie coraz większej ich liczby, jak i o kierowanie ich do coraz większej ilości inicjatyw pastoralnych.

Barierą istniejącą w komunikacji poziomej na terenie parafii jest krążenie dużej ilości informacji nieprawdziwych lub nie całkiem prawdziwych. Odpowiedzialność za to w pewnym stopniu ponoszą proboszczowie, którzy nie przekazują informacji wyczerpujących, dając tym samym okazję do domysłów, a nawet plotek. Poprawa skuteczności w komunikacji poziomej, nieformalnej, jest zatem zależna od duszpasterzy, których zadaniem jest udzielanie pełnych informacji. Mogą oni ponadto wykorzystywać nieformalną sieć informacji istniejącą w parafii do przekazywania wiadomości. Walorem komunikacji nieformalnej jest to, że informacje rozchodzą się w niej szybko. Problemem jest natomiast to, że wskutek przekazywania $\mathrm{z}$ ust do ust ulegają zniekształceniom, przyczyniając się pośrednio do powstawania barier komunikacyjnych.

Komunikacja jest istotnym elementem życia religijnego w parafii i duszpasterstwa parafialnego. Podobnie jak w innych organizacjach, natrafia ona na bariery, które w różny sposób ją utrudniają. Spojrzenie na nie w świetle nauk o zarządzaniu pomaga w zrozumieniu ich przyczyn i sprzyja znajdowaniu sposobów poprawy skuteczności komunikowania w parafii. Ze względu na kierowniczą rolę proboszcza w parafii, wskazaną przez nauczanie i prawodawstwo kościelne, to na nim w pierwszej kolejności spoczywa odpowiedzialność za inicjatywy zmierzające do rozwijania komunikacji wewnątrzparafialnej. Na nim również spoczywa obowiązek podejmowania działań poprawiających skuteczność tego procesu. 


\section{BIBLIOGRAFIA}

CIEŚLIK Ireneusz, Przezwyciężyć kryzys parafii, w: Nowa ewangelizacja u progu Trzeciego Tysiąclecia. Program duszpasterski na rok 2000/2001, red. E. Szczotok, R. Kempny, A. Liskowacka, Katowice: Kuria Metropolitalna 2000, s. 159-167.

GRIFFIN Ricky W., Podstawy zarządzania organizacjami, Warszawa: Wydawnictwo Naukowe PWN 2004.

KACZOR Adam, Kancelaria parafialna, w: Teologia pastoralna, red. R. Kamiński, t. II, Lublin: Atla 2 2002, s. 86-92.

KAMIŃSKI Ryszard, Działalność zbawcza Kościoła w teorii i praktyce pastoralnej, Lublin: Wydawnictwo KUL 2007.

KAMIŃSKI Ryszard, Parafia miejscem realizacji duszpasterstwa, w: Teologia pastoralna, red. R. Kamiński, t. II, Lublin: Atla 2 2002, s. 11-78.

KemPNy Roman, Jaka parafia u progu Trzeciego Tysiąclecia?, w: Nowa ewangelizacja u progu Trzeciego Tysiąclecia. Program duszpasterski na rok 2000/2001, red. E. Szczotok, R. Kempny, A. Liskowacka, Katowice: Kuria Metropolitalna 2000, s. 150-158.

LIPIEC Dariusz, Problemy we współpracy duchowieństwa i laikatu, „Roczniki Teologiczne” 50(2003), z. 6, s. 231-246.

Petrowa-Wasilewicz Anna, Parafia przyszłości - dom otwartych drzwi, w: Nowa ewangelizacja u progu Trzeciego Tysiąclecia. Program duszpasterski na rok 2000/2001, red. E. Szczotok, R. Kempny, A. Liskowacka, Katowice: Kuria Metropolitalna 2000, s. 168-174.

SOBÓR WATYKAŃSKi II, Dekret o pasterskich zadaniach Biskupów w Kościele „Christus Dominus” (28.10.1965), w: Sobór Watykański II. Konstytucje Dekrety Deklaracje, Poznań: Pallottinum 2002, s. 236-258.

SobÓR WATYKAŃSKi II, Dekret o posłudze i życiu prezbiterów „Presbyterorum ordinis” (7.12.1965), w: Sobór Watykański II. Konstytucje, dekrety, deklaracje, Poznań: Pallottinum 2002, s. 478-508.

Stoner James A. F., Freeman Edward R., Gilbert Daniel R., Kierowanie, Warszawa: Polskie Wydawnictwo Ekonomiczne 2011.

WoźNIAK Jarosław P., Rozwój mediów w przekazie wiary w archidiecezji lubelskiej po roku 1989, Lublin: Gaudium 2015.

ŻĄDŁO Andrzej, Modele organizacji duszpasterstwa parafialnego, w: Nowa ewangelizacja u progu Trzeciego Tysiąclecia. Program duszpasterski na rok 2000/2001, red. E. Szczotok, R. Kempny, A. Liskowacka, Katowice: Kuria Metropolitalna 2000, s. 175-186. 


\section{BARIERY W KOMUNIKACJI I POPRAWA JEJ SKUTECZNOŚCI WE WSPÓLNOCIE PARAFIALNEJ}

\section{Streszczenie}

Artykuł jest poświęcony barierom w komunikacji we wspólnocie parafialnej i sposobom ich przezwyciężania. W pierwszej części zostały omówione bariery komunikacyjne między proboszczem a jego duchownymi współpracownikami. Następnie przedstawione zostały problemy w komunikacji między proboszczem a aktywnie zaangażowanymi świeckimi współpracownikami. Ostatnia część została poświęcona barierom komunikacyjnym między proboszczem a ogółem parafian. W procesie komunikacji na terenie parafii podstawową rolę odgrywa proboszcz jako jej pasterz, dlatego w artykule poświęcono uwagę przede wszystkim trudnościom w komunikowaniu się przez niego ze współpracownikami i parafianami. Trudności komunikacyjne między parafianami nie mają tak dużego znaczenia w życiu i działalności wspólnoty parafialnej.

Słowa kluczowe: parafia; komunikacja; bariery komunikacyjne; skuteczność komunikacji; proboszcz; parafianie. 